5. Lewy R. Immunizations among hospital personnel.J Occup Med 1987;29:433-436.

6. Weingarten S, Riedniger M, Bolton LB, Miles P, Ault M. Barriers to influenza vaccine acceptance: a survey of physicians and nurses. Am J Infect Control 1989;17:202-207.

7. Girasek DC. Increasing hospital staff compliance with influenza immunizations. Am J Public Health 1990;80:1272-1273.

8. Christian MA. Influenza and hepatitis B vaccine acceptance; a survey of healthcare workers. Am J Infect Control 1991;19:177184.

9. Ohrt CK, McKinney WP. Achieving compliance with influenza immunization of medical housestaff and students. A randomized controlled trial. JAMA 1992;267:1377-1380.

10. Thomas DR, Winsted B, Koontz C. Improving neglected influenza vaccination among healthcare workers in long-term care. J Am Geriatr Soc 1993;41:928-930.

11. Schiefele DW, Bjornson G, Johnston J. Evaluation of adverse events after influenza vaccination in hospital personnel. Can Med Assoc J 1990;142:27-130.

12. al-Mazrou A, Schiefele DW, Soong T, Bjornson G. Comparison of adverse reactions to whole-virion and split-virion influenza vaccines in hospital personnel. Can Med Assoc J 1991;145:213-218.

13. Schoenbaum SC. Developing effective systems for delivery of vaccines. Infect Dis Clin North Am 1990;4:199-209.

14. Buffington J, Bell KM, LaForce FM, et al. A target-based model for increasing influenza immunizations in private practice. $J$ Gen Intern Med 1991;6:204-209.

15. Fiebach N, Beckett W. Prevention of respiratory infections in adults. Influenza and pneumococcal vaccines. Arch Intern Med 1994;154:2545-2557.

16. Merkel PA, Caputo CG. Evaluation of a simple office-based strategy for increasing influenza vaccine administration and the effect of differing reimbursement plans on the patient acceptance rate. J Gen Intern Med 1994;9:679-683.

17. Nichol KL. Long-term success with the national health objective for influenza vaccination. An institution-wide model. $J$ Gen Intern Med 1992;7:595-600.

18. Foster DA, Talsma A, Furumoto-Dawson A, et al. Influenza vaccine effectiveness in preventing hospitalization for pneumonia in the elderly. Am J Epidemiol 1992;136:296-307.

19. Fedson DS, Wajda A, Nicol JP, Hammond GW, Kaiser DL, Roos LL. Clinical effectiveness of influenza vaccination in Manitoba. JAMA 1993;270:1956-1961.

20. Nichol KL, Margolis KL, Wuorenma J, von Sternberg T. The efficacy and cost-effectiveness of vaccination against influenza among elderly persons living in the community. $N$ Engl J Med 1994;331:778-784.

21. Yassi A, Kettner J, Hammond G, Cheang M, McGill M. Effectiveness and cost-benefit of an influenza vaccination program for healthcare workers. Can J Infect Dis 1991;2:101-108.

\title{
Varicella Vaccine Pregnancy Registry
}

Gina Pugliese, RN, MS

Martin S. Favero, PhD Medical News Editors

Varivax (Merck \& Co, Inc, West Point, PA), a live attenuated virus vaccine for preventing chickenpox, recently has been licensed for children aged $>12$ months. Adults without a reliable history of chickenpox also may receive the vaccine. However, because no data exist on the effects of Varivax on fetal development and because natural varicella infection can cause a complex of congenital anom- alies (ie, congenital varicella syndrome), the package circular states that the vaccine should not be administered during pregnancy and that pregnancy should be avoided for 3 months after vaccination.

Merck \& Co, Inc, in collaboration with the CDC, has established a registry to follow the outcomes of pregnancy when women are vaccinated within 3 months before pregnancy or at any time during pregnancy. Patients and healthcare providers should report any vaccination with Varivax during this period to the reg- istry (telephone 800-986-8999 or mail to Merck Research Laboratories, Worldwide Product Safety and Epidemiology, BLA-31, West Point, PA 19486). Questions regarding the registry should be directed to Dr. Jeanne Manson, 610-397-7290 (call collect), or fax to 610-397-2328. An annual report will be sent to healthcare providers participating in the registry.

FROM: Centers for Disease Control and Prevention. Establishment of Varivax pregnancy register. $M M W R$ 1996;45(11):239. 